\title{
NOVI PRILOZI ZA ISTRAŽIVANJE AKCIJE „DESETI TRAVNJA“: NEPOZNATO PISMO ANTE PAVELIĆA IZ SRPNJA 1948.
}

\author{
Ante DELIĆ \\ Sveučilište u Zadru \\ Zadar, Hrvatska
}

\author{
UDK:323.28-054.73(497.1) \\ 32-05Pavelić,A. \\ DOI: https://doi.org/10.21857/yvjrdcq1vy \\ Izvorni znanstveni rad \\ Prihvaćeno: 14. srpnja 2018
}

S obzirom na to da se o ovoj temi još uvijek uglavnom zaključuje na temelju objavljenih svjedočanstava sudionika u čijim interpretacijama postoji niz nelogičnosti, autor na temelju dosadašnje literature i do sada nepoznatih i neistraženih izvora dodatno rasvjetljuje nedovoljno istraženu ulogu Ante Pavelića u vezi s akcijom „Deseti travnja“.

Ključne riječi: Ante Pavelić, Božidar Kavran, Lovro Sušić, Ivica Krilić, Mate Frković, akcija „Deseti travnja“, zapadne obavještajne službe.

\section{UVOD}

Rad predstavlja nastavak istraživanja akcije „Deseti travnja“, poglavito na temelju nekorištene i nepoznate građe u smjeru daljnjeg rasvjetljavanja uloge Ante Pavelića u samoj akciji. ${ }^{1}$ Posljedično tomu, ukazat ćemo na neke smjernice prema kojima bi trebalo pristupiti daljnjem istraživanju ove teme. $\mathrm{O}$ akciji „Deseti travnja“2 postoje brojna otvorena pitanja na koja još uvijek nema znanstveno utemeljenih odgovora, a nemali dio spoznaja uglavnom se crpi iz objavljenih svjedočanstava preživjelih sudionika. Do danas još uvijek nemamo znanstvenu monografiju o akciji. ${ }^{3}$ Nedavno je objavljena i prva monografija o povijesti hrvatske političke emigracije koja se među ostalim bavi i raščlambom same akcije. Dodatno rasvjetljava njezin tijek te progovara o nekim do sada zanemarivanim važnim dugoročnim posljedicama akcije. ${ }^{4}$

1 Rezultate dosadašnjih istraživanja vidi u: Ante Delić, Djelovanje Ante Pavelića 1945.-1953. godine, Doktorska disertacija, Sveučilište u Zadru, Zadar, 2016., 61 - 143.

2 Jedan od najpoznatijih organiziranih oružanih pothvata protiv jugoslavenskog komunističkog režima. Često se koristi i netočan naziv „Kavranova akcija“, a u manjoj mjeri i akcija „Hrvatskog državnog vodstva“. U jugoslavenskoj publicistici „Operacija Gvardijan“.

3 Dosada jedina monografija o križarskom pokretu:Zdenko RADELIĆ, Križari-gerila u Hrvatskoj 19451950, Hrvatski institut za povijest - Dom i svijet, Zagreb, 2002., 115, i II. izdanje, Zagreb, 2011.

4 Kazimir Katalinić, Od poraza do pobjede. Povijest hrvatske političke emigracije 1945.-1990., Svezak I. - 1945.-1959., Zagreb, 2017., 57 - 87. 
Bez nekoliko riječi o kontekstu i okolnostima unutar kojih je sazrijevala ideja o potrebi planiranja protujugoslavenskog i protukomunističkog otpora nije moguće razumjeti samu ideju akcije. Ukratko, slom $\mathrm{NDH}$ doveo je do demoralizacije velikog broja ljudi. Borba za preživljavanje, strah od izručenja jugoslavenskim vlastima, uz nezaobilazno očekivanje sukoba Zapada i Istoka, presudni su motivi za početno okupljanje. Sam Pavelić - koji unatoč slomu i dalje mnogima ostaje simbol - prelazi u pozadinu te predaje Mačeku vodeću ulogu u zastupanju „hrvatske stvari“. Međutim, vrijeme će pokazati kontinuitet Mačekove tradicionalne pasivnosti i naklonjenost nadnacionalnim političkim koncepcijama.

Niz glasina o rastućem otporu u zemlji, koje je bilo nemoguće objektivno procijeniti, motiviraju niz pojedinaca na povratak u zemlju. Kakvo je stanje duha vladalo među izbjeglim Hrvatima jasno nam oslikava svjedočanstvo jednog suvremenika:

„Obćenito je poznato da je u srdcima svih Hrvata, koji su od svibnja 1945. pa do danas napustili domovinu ispred komunističke tiranije, gorila neutaživa želja vratiti se u domovinu. (...) Ta čežnja je pola naše duše. Ona utječe na naše značaje, na naša djela i odluke, izgradjujući još uviek u nama i oko nas svoj posebni ambient, kojemu se - tko manje, tko više, - svi mi prepuštamo i pokoravamo. Ova vruća želja hrani našu nadu, a nada podržaje duh odpornosti i izdržljivosti, bez čega ne bi bilo ono što jesmo i moramo biti. U tome se do danas nismo promienili. Zar je onda čuditi se što je kod nekih čežnja prešla u neodoljivu strast. Razum i strast se u nama sukobljavaju, jer je kod nekoga nestala strpljivost, nekome klonule nade, a netko je bogme i ambiciozan, sanjajući o 'triumfalnom povratku'. Ima tu svega po nešto.... ."

\section{PITANJE ODNOSA U VODSTVU - TEMELJNI PREDUVJET U ISTRAŽIVANJU AKCIJE}

Kod istraživanja Pavelićeve uloge potrebno je imati u vidu i međusobne odnose bivših visokih dužnosnika NDH poslije rata, nakon čega se nužno postavlja pitanje o autonomiji koju su u svom djelovanju imali Božidar Kavran, ${ }^{6}$

$5 \quad$ Ivan ŠTIR, puk., Rieč vojnika: Politika strasti i politika hladnog razuma, Drina. Vjestnik hrvatskih oružanih snaga, br. 8-12. prosinac 1955., god. V., 336.

6 Božidar Kavran, (Zagreb, 1913. - Zagreb, ?), ustaški dužnosnik. Član domovinskog ustaškog pokreta od 1937. Za vrijeme NDH obnašao razne dužnosti: stožernik Ustaškog stožera za Zagreb, zamjenik postrojnika i upravni zapovjednik Ustaškog pokreta. Na kraju rata povlači se u Austriju. Britanske vojne vlasti ga uhićuju te bježi iz logora. Ostaje u Austriji i angažira se na 
Lovro Sušić ${ }^{7}$ i Mate Frković ${ }^{8}$ kao vodeći trojac pothvata. Bez toga je nemoguće cjelovito istražiti tijek i propast akcije.

Kad je riječ o međusobnom odnosu Pavelića i Kavrana, činjenica je da su Sušić i Kavran - od trenutka kada je Pavelić živio u njihovoj blizini - nastojali kod bivših ministara (a nakon njih i kod dužnosnika nižega ranga) stvoriti dojam uske Kavranove povezanosti s Pavelićem. Nedvojbeno su Kavran i Sušić (i ne samo oni) bili svjesni snage Pavelićeva imena među izbjeglicama (unatoč katastrofalnom slomu) te da rad na pothvatu stoji ili pada na Pavelićevom imenu. Drugim riječima, nerijetko se previđa da je jedina mogućnost pridobivanja većeg broja izbjeglica za sudjelovanje u akciji bila kroz stvaranje i održavanje dojma kako Pavelić u potpunosti stoji iza cjelokupnog rada.

Kavranovo djelovanje treba promatrati i u kontekstu od ranije poznatoga stava generala Ante Moškova i Vilka Pečnikara prema Paveliću. Naime, potonji su poslije sloma djelovali na svoju ruku i nisu se previše obazirali na Pavelićevo mišljenje, a Kavranu je to bilo dobro poznato te je zasigurno u određenoj mjeri utjecalo i na način njegova rada.

Naravno, postavlja se pitanje može li se u tom kontekstu uopće govoriti u terminima (ne)poslušnosti, jer potpuno je nemoguće da bi Pavelić odobrio svaku pojedinačnu akciju (diverziju) koju su npr. 1931. iz Mađarske poduzimali predratni Pavelićevi suradnici Gustav Perčec i Stanko Hranilović. Također,

protujugoslavenskoj djelatnosti s ciljem podizanja ustanka u zemlji. Prilikom prelaska u domovinu 1948., uhićen od strane UDB-e te osuđen na smrt. Službeni datum smrti je 31. kolovoz 1948., međutim prema dostupnim dokumentima bio je živ početkom 1949. Točan datum smrti do danas je nepoznat. Navedeno prema: Tko je tko u NDH, Hrvatska 1941. - 1945., ur. Darko Stuparić et al., Zagreb, 1997., 185 - 186.

7 Lovro Sušić, (Mrkopalj, 1891. - Caracas, 1972.), odvjetnik i političar. Doktorirao pravo u Zagrebu. Brani političke protivnike jugoslavenskog kraljevskog režima. Izabran za narodnog zastupnika na listi HSS-a na izborima 1935. i 1938. Istupio protiv sporazuma Cvetković-Maček. Prvi ministar narodnog gospodarstva u vladi NDH, zatim ministar udružbe te ministar postrojnik. Doglavnik i nositelj naslova viteza. Povlači se u Austriju gdje je vrlo aktivan u protujugoslavenskom radu. Godinu dana poslije propasti akcije prelazi u Italiju, zatim u Španjolsku i na koncu 1951. u Venezuelu. (Nav. prema: Tko je tko u NDH, 372) Od tada se politički pasivizira, te više ne spada u krug bliskih Pavelićevih suradnika, ali „on nastoji da u odnosima s Pavelićem ostane sa svoje strane skrajnje korektan“. Karlo Mirth, Dr. Lovro Sušić (1891-1972), Croatia Press, New York, br. 1-2/1973., 24.

8 Mate Frković, (Lički Novi, 1901. - Buenos Aires, 1987.), liječnik i političar. Za vrijeme kraljevske Jugoslavije progonjen zbog političkog djelovanja. Obnašao razne dužnosti nakon proglašenja NDH: ustaški povjerenik za Varaždin, stožernik Velike župe Zagorje, doglavnik i ministar unutarnjih poslova. Povlači se u Austriju gdje se angažira na organizaciji protujugoslavenskog otpora. Odvaja se od Pavelića i 1950. pristupa HNO-u Branimira Jelića. Poslije raslojavanja u HNO-u, 1960-ih prelazi u Argentinu. Opširnije u: Tko je tko u NDH, 122. 
Pavelić je iz zatvora u Torinu mogao davati samo opće naputke, a nije mogao operativno upravljati ustaškom organizacijom. Ako dakle apsolutnog posluha nije bilo ni tada, kako ga je moglo biti nakon 1945. kada je bilo jasno da je Pavelićevo vrijeme prošlo. Štoviše, stanje je sada bilo kudikamo teže jer je Pavelić morao strogo kriti mjesto svog boravka.

Prije svog prelaska u zemlju Vladimir Sabolić ${ }^{9}$ razgovarao je sa Sušićem u Austriji o nekim okolnostima vezanim za provedbu akcije. Sušić mu je iznio da su veze s Pavelićem „slabije i rijedje“, no poslije Kavranova povratka iz Italije „iza 23. V. 1948. g., kazao mi je Sušić da je sada uredjeno da će veze biti mnogo češće i brže“. Također, da vodstvo u Austriji radi „sve prema uputama i dogovoru $s$ poglavnikom iako se još momentalno to ne smije znati i s njegovim imenom izlaziti u javnost" ${ }^{10}$

Neki autori tvrde kako veza s Pavelićem poslije njegova prelaska u Italiju u rujnu 1946. „nije bila prekinuta, ali isto tako nije mogla biti onako intenzivna kao u vrijeme dok je on živio u Austriji, jer je morala ići uglavnom putem povjerljivih teklića. Zato Pavelić i nije mogao iz Italije izravno upravljati akcijom, nego je davao naputke i savjete na temelju izvješća" koja su mu slali Sušić i Kavran. ${ }^{11}$ Međutim, ni jedno od tih izvješća do danas nije pronađeno niti sa sigurnošću možemo tvrditi koliko ih je uopće bilo.

Iako nije potpuno jasno kada je i čijom odlukom Ante Vrban pozvan u Austriju, ${ }^{12}$ nesporno je da se njegov drugi prelazak u zemlju dogodio kad je Pavelić bio u Pustritzu, odnosno da je Pavelić znao za njega i odobrio ga. Vrban se po dolasku iz Italije upoznao s Kavranom u Lind ob Veldenu i govorio mu o svom prebacivanju u domovinu. Kavran mu je rekao da se može prebaciti, „a

9 Dr. Vladimir Sabolić, odvjetnik i veliki župan (Križevci, 31. VII. 1900. - Zagreb, 31.VIII. 1948.). Godine 1938. izabran za tajnika Kotarskog odbora HSS-a u Đurđevcu, a 1939. istupa iz HSS-a i postaje organizator ustaškog pokreta u đurđevačkom kraju. Nakon proglašenja NDH imenovan za ustaškog povjerenika za kotar Đurđevac, zatim za velikog župana Velike župe Posavje te velikog župana Velike župe Bilogora. Obnašao je i dužnost državnog tajnika, a uoči sloma NDH ravnatelja unutarnje uprave MUP-a. Povlači se u Austriju te u proljeće 1948. prelazi u Hrvatsku u sklopu akcije „Deseti travnja“. Po prelasku granice je uhićen i 27. VIII. 1948. osuđen na smrt. Tko je tko u NDH, $353-354$.

10 Hrvatski državni arhiv, Služba državne sigurnosti, Republički sekretarijat unutrašnjih poslova Socijalističke Republike Hrvatske, (HDA, SDS RSUP-a SRH), 015.7-11., Zapisnik saslušanja Vladimira Sabolića, 29.

11 K. Katalinić, Od poraza do pobjede, 61.

12 Govoreći o Vrbanovu odlasku, Sušić je „rekao da je Džal pokušao otpremiti u zemlju nekoliko grupa, da je te pokušaje činio još i prije dolaska Pavelića u englesku zonu“. HR-HDA-1561. SDS RSUP-a SRH., Dosje Božidara Kavrana, 61. 
kada se vrati neka o učinjenom izvjesti onoga koji ga je slao" ${ }^{13}$ Dakle, vidljivo je da su odnosi među vodećim članovima pothvata bili zategnuti, što se redovito previđa. ${ }^{14} \mathrm{Iz}$ ovog Vrbanova slučaja jasno je da su takvi odnosi utjecali i na uspješnost priprema same akcije, iako je i Pavelić znao za Vrbanov odlazak u domovinu i odobrio ga.

Pozivajući se na svjedočanstva sudionika akcije, Katalinić navodi: „Znajući da je Pavelić očekivao Vrbanov povratak, Kavran ga je izvijestio o Vrbanovu izvješću i dojmovima." ${ }^{15}$ Govoreći o Vrbanu poslije propasti akcije, Sušić je u javnoj „Obavijesti“ iznio kako je Vrban prvi „donio vijesti iz šume“ te da je našao „posvuda manje ili veće grupe hrvatske vojske“ koje su bile nepovezane i u nedostatku viših časnika. ${ }^{16}$ Međutim, u pismu Luburiću od 19. lipnja, tri tjedna prije propasti akcije, Sušić iznosi drugačiju ocjenu:

„Njegovo (Vrbanovo op. a.) je izvješće bilo porazno, barem prema onome, što smo mi zamišljali. Tek dvie donekle jače skupine i to u Slavoniji i Hercegovini. Inače sve raztepeno u posve male skupinice po desetak dvadesetak ljudi, svaka prepuštena sama sebi, nepovezana sa najbližom skupinom, skoro nigdje kod njih častnika a često ni dočastnika, većinom nedisciplinirane, mnoge skoro prave pljačkaške bande, dešperateri, što spašavaju glave... " " ${ }^{\prime 17}$

Autori koji tvrde da je Pavelić obaviješten o Vrbanovu izvješću trebali bi odgovoriti na pitanje koja je verzija njegova izvješća došla do Pavelića.

U svibnju 1946. Pavelić je sa sinom okvirno dogovorio svoje buduće prebacivanje u Italiju, dok je detalje prelaska naknadno dogovorio s Jakovom

13 HR-HDA-1561. SDS RSUP-a SRH., Dosje Božidara Kavrana, 61.

14 „On (Džal op. a.) je pokušavao slati pretežno časnike ustaške obrane, ali većina njih nisu uspjeli prodrijeti u zemlju, jer su ljudi bili neoprezni i neozbiljni na putu. Kazao mi je (Sušić op. a.) da se sa jednom grupom petorice prebacivao i Vrban i od cijele grupe u zemlju se uspio probiti samo Vrban i Čavar, dok su se ostali vratili.“ HR-HDA-1561. SDS RSUP-a SRH., Dosje Božidara Kavrana, 61.

15 K. Katalinić, Od poraza do pobjede, 60.

16 Nikola Čol a , Akcija Deseti travanj u svijetlu krunskog svjedočanstva Ivana Prusca i dokumentacije, Središnjica za proučavanje hrvatske povijesti, Padova, 1989., 87. „Sa šumom nismo imali nikakve veze. Mnogi su, istina, dolazili, nu njihove viesti bile su puke bablje priče ili fantazija.“ N. ČolAK, Akcija Deseti travnja, 437 - 438.

17 N. Čolak, Akcija Deseti travnja, 437., „U zadnju subotu dne 29. V. t.g. (1947., op. a.) kad sam bio kod Sušića kazao mi je ovaj da se u Francuskoj nalazi i Luburić“. On je „svojedobno ranjen u Hrvatskoj u nogu te se je prebacio u Francusku gdje se nalazio u bolnici na lječenju. (...) Sušić mi je rekao da bi Luburić htio u Hrvatsku u šumu, no da je to obzirom na njegovu osobu i rad u prošlosti kao i sadanje prilike, nemoguće." HR-HDA-1561. SDS RSUP-a SRH, 015.7-11., Zapisnik saslušanja Vladimira Sabolića, 38. 
Džalom ${ }^{18}$ (s kojim je neko vrijeme zajedno stanovao) te o svemu do samoga polaska nije govorio Kavranu i Sušiću. ${ }^{19}$ Krajem ljeta 1946. Kavran i Sušić saznali su da je Pavelić odlučio otići u Italiju. Bili su iznimno nezadovoljni tom Pavelićevom odlukom, a Kavrana je povrh svega brinulo kako će u buduće komunicirati s Pavelićem. To mu je pitanje u više navrata postavljao, prvenstveno jer je znao da je Pavelić poslije promjene skrovišta „uvijek sa svim osobama $s$ kojima je do tada bio u vezi potpuno prekidao kontakt“. Pavelić je rekao da „od tog pravila neće otstupiti“ ${ }^{20}$ Prema Italiji su krenuli u noći 12. rujna $1946 .{ }^{21}$ Nekoliko dana po dolasku u Italiju Pavelić i Kavran su se razdvojili i to je bio njihov posljednji susret.

Svećenik Krunoslav Draganović, središnja osoba među hrvatskim poslijeratnim izbjeglicama i jedan od najboljih poznavatelja poslijeratnih prilika u emigraciji, za vodstvo akcije u Austriji je naveo: „Bilo bi važno doznati, da li je ono bilo izabrano ili imenovano, i od koga. U Italiji imalo je ono svoje povjereništvo, Dragu Jileka i Jolu Bujanovića. Među njima nije bilo savršene suradnje i povjerenja, možda odraz dvostrukog kolosijeka mišljenja i rada na samom vrhu." 22

Dodatno svjetlo na odnose u vodstvu akcije pruža i istražni zapisnik Vladimira Sabolića u kojem on navodi da je na sastanku u Austriji sredinom veljače 1948. Kavran govorio o svom sukobu s Džalom te kako je M. Frković rekao da će on taj spor riješiti. ${ }^{23}$ Kavran je tvrdio da će Džal pokušati ubaciti svoje ljude u zemlju i preko njih uspostaviti vezu s Amerikancima, neovisno o Kavranu te da Džala u tome treba spriječiti. Međutim, Kavran je mišljenja kako Džal ,ipak ne bi ništa radio protiv poglavnika i bez njegova znanja“. Osim sukoba s Džalom, Sabolić navodi da Kavran ni s Frkovićem nije u dobrim odnosima. ${ }^{24}$

18 Jakov Džal, ustaški pukovnik (Bihać, 22. IV. 1910. -?). Brat Franje Džala, zrakoplovnog pukovnika. Završio pravni fakultet u Zagrebu. Za vrijeme NDH obnašao dužnosti: upravitelj bihaćkog kotara, nadstojnik Odsjeka GRAVSIGUR-a za upravu logora. Pred slom NDH promaknut u čin pukovnika redarstvene straže i postavljen zapovjednikom 1. obrambenog ustaškog zdruga. Povukao se u Austriju te je kasnije postao upravitelj Škole za sabotaže u Bavarskoj. Tko je tko u NDH, 108.

19 HR-HDA-1561. SDS RSUP-a SRH., Dosje Božidara Kavrana, 48. Kavran se nije mirio ni s činjenicom da je Pavelić svoj put isplanirao s Džalom.

20 Kavran je potom inzistirao biti dijelom Pavelićeve pratnje kod prebacivanja u Italiju, iako nije bio u prvotnom planu. Pavelić je pristao uz uvjet „da bi do izvjesnog mjesta išao s njime, a kada mi on reče da dalje ne mogu, vratio bih se u Austriju“. HR-HDA-1561. SDS RSUP-a SRH., Dosje Božidara Kavrana, 48.

21 Jere JAREb, Zlato i novac NDH izneseni u inozemstvo 1944. i 1945., Zagreb, 1997., 320, bilj. 53.

22 Vinko Ni Kolić, Pred vratima domovine II., Zagreb, 1995., 326.

23 HR-HDA-1561. SDS RSUP-a SRH, 015.7-11., Zapisnik saslušanja Vladimira Sabolića, 12.

24 HR-HDA-1561. SDS RSUP-a SRH, 015.7-11., Zapisnik saslušanja Vladimira Sabolića, 68 - 69. 
Treba spomenuti i zanimljivo poslijeratno svjedočanstvo o Džalovoj ulozi u akciji, koje treba promatrati i u svjetlu nezaobilaznih emigrantskih previranja, $s$ obzirom na to da je autor politički bio blizak HSS-u:

„Zašto se prešućuje onoga koji danas kaže i tuži se, da mu je pok. Božo Kavran kidao 'konce', gdje je samo mogao? Zašto prešućuje spomenuti čovjeka, koji se je, uprkos toga, što nije posjedovao nikakvog vojničkog znanja ni iskustva, prihvatio posla, što je zahtjevao najveće vojničko zvanje i iskustvo. Zašto se prešućuje čovjeka koji je uputio prvu grupu u domovinu, t.j., uputio je Miloša, Vrbana i Grgića, čije je hapšenje prouzrokovalo cijelu tragediju? Zašto se prešućuje čovjeka, koji je radio pomoću neke 'strane obavještajne službe' i kojeg je ta 'služba', reče, 'premalo plaćala'? Zašto se taj gospodin ne javi sam danas i ne unese malo više svijetla u cijeli taj tragični slučaj ?" 25

Jedna od najupućenijih osoba o Kavranovu načinu rada i stupnju autonomije koju je pri tome imao jest Sušić. On je poslije propasti akcije u svojoj javnoj „Obavijesti“ od 20. srpnja 1948. iznio kronologiju same akcije, motive njezina pokretanja te osvrt na njezinu propast. Naravno, motiviran i time „da bi se, nakon njezina tragičnog svršetka, opravdavalo samu akciju“.:26

„Organizaciju opreme u domovinu i stalne veze sa domovinom kao uobće cieli domovinski sektor preuzeo je izključivo u svoje ruke Božo Kavran, koji je još prije rata aktivno sudjelovao u ilegalnom konspirativnom radu. Jer se je tu radilo o najdelikatnijoj zadaći, gdje je potrebna najveća tajnovitost u radu, to je on taj zadatak preuzeo uz uvjet, da mu u taj njegov sektor rada nitko ne ulazi osim onih, koje on za taj posao odnosno za pojedine zadaće izabere, što je uostalom i posve razumljivo." ${ }^{27}$

S druge strane, dok je akcija bila u punom zamahu, Sušić je više puta isticao da je Kavran njegov zamjenik „s kojim radim od početka najtjesnije i najintimnije“ ${ }^{28}$ Da je bilo onih koji su i prije propasti akcije upozoravali na metodologiju rada, osobito kad je riječ o „tajnovitosti u radu“, pokazuje i Sušićev odgovor na pismo nekadašnjem ministarskom kolegi Janku Tortiću:

25 M.G.P. (Marinko Gordan Polić), Luburić u svijetlu istine, Hrvatski Glas, 3. rujna 1956.

26 K. Katalinić, Od poraza do pobjede, 61, bilj. 98.

27 Javna „Obavijest“ od 20. 7. 1948. N. Čolak, Akcija Deseti travnja, 88. S druge strane, u okružnici napisanoj dva mjeseca kasnije Sušić navodi da se ubuduće treba raditi „najkonspirativnije“ te da „za cieli rad ne smie nitko znati“. N. Čola K, Akcija Deseti travnja, 357.

28 Sušić u pismu Vjekoslavu Maksu Luburiću od 19. 6. 1948. N. Čola , Akcija Deseti travnja, 438. Također, u nekim slučajevima Sušić „po predlogu Mateka“, tj. Kavrana poziva pojedince da idu „u domovinu“. N. Čol AK, Akcija Deseti travnja, 419. 
„Imaš pravo, da prigovaraš, ako se ne radi oprezno, a napose ako se o tome brblja, a također da upozoravaš na nepouzdanost pojedinih ljudi, koji dolaze $s$ tim u vezu, pa sam ja to Mateku (Kavranu, op. a.) javio time, da se napravi red. $\mathrm{Nu}$ inače bolje je, da ni Ti ni mi u te stvari ne ulazimo, barem ne neposredno, pa da i ne znamo za sve, jer napokon i podjela rada i povjerenje prema onomu, koji stanovite poslove preuzme, to traži... . "29

Međutim, slično kao u ranijem slučaju vezano za ocjenu Vrbanova izvještaja, poslije propasti akcije Sušić je iznio sljedeću ocjenu Kavranova rada: „Neumorna njegova požrtvovnost i najpomnija opreznost $u$ njegovu radu bile su obće poznate, i ljubomorno čuvanje tajnosti cieloga rada često mu je bilo i zamjeravano i označivano kao znak nepovjerenja i prema najbližima i najpovjerljivijim. “ ${ }^{\text {"30 }}$

\section{Analiza pisma:}

a.) Tko, komu, kada i gdje?

Kad je riječ o Pavelićevoj ulozi u akciji, trebamo razlikovati njezine dvije faze. Prva faza uključivala je prikupljanje pouzdanih saznanja o stanju u zemlji te imala za cilj uspostavljanje stabilne i sigurne veze s njome. Druga faza je operativna i podrazumijeva djelovanje u domovini, ali isključivo poslije uspješnog završetka prve faze djelovanja. Prema onome što znamo iz dosadašnjih istraživanja, Pavelić je inzistirao na ostvarenju prve faze, kao nezaobilaznog preduvjeta za nastavak djelovanja prema domovini. ${ }^{31}$ Posebno je pitanje u kojoj su mjeri njegovo mišljenje dijelili vodeći ljudi akcije.

Drago Jilek iznio je u poslijeratnoj istrazi da je za vrijeme svog boravka u Austriji početkom rujna 1946. preko Kavrana zatražio „Pavelićevo mišljenje“, s obzirom na to da se Pavelić tada još uvijek nalazio u Austriji i bio dostupan Kavranu. Među ostalim, Jilek je pitao i o uspostavljanju veze s domovinom kroz „tri kanala“:

„Jedan koji ima služiti isključivo za kurirsku vezu, drugi za ubacivanje grupa. /Ja sam mislio samo na terorističke i obavještajne grupe, a ne organizatorske, kako je to Kavran poslije radio, koje su tek imale organizirati vojsku. Polazio sam sa stanovišta da vojska i zapovjednici postoje i da prije svega treba s njima uspostaviti vezu. Kavran je naprotiv slao grupe, da od ničega nešto stvore./ I treći

29 Pismo Lovre Sušića Javitu (Janku Tortiću, op. a.) od 12. 4. 1948. u N. ČolaK, Akcija Deseti travnja, 404.

30 Javna „Obavijest“" od 20.7. 1948. N. Čolak, Akcija Deseti travnja, 89.

31 Opš. A. Delić, Djelovanje Ante Pavelića 1945.-1953. godine, 41 - 102. 
kanal za ubacivanje materijala i to materijal koji bi imao služiti za terorističke akcije, za obavještajnu službu i promidž(b)eni /propagandni/ materijal. ${ }^{\text {“32 }}$

Takav način „uspostavljanja i održavanja veze sa Domovinom, odobrio je (Pavelić, op. a.) u cijelosti“. Osim toga, Jileka je zanimalo i „Pavelićevo mišljenje je li oportuno početi sa terorističkom akcijom u Zemlji. Isto tako sa atentatima na istaknute pojedine osobe“" Pavelić „savjetuje kloniti se terorističke akcije radi odmazda, koje bi uslijedile nad narodom. Nije protiv atentata na pojedine istaknute osobe." ${ }^{\text {"33 }}$

O Pavelićevu stavu i ulozi u akciji „Deseti travanj” govori nam i dosad nepoznato i neobjavljeno Pavelićevo pismo nastalo nedugo nakon saznanja o propasti akcije, ${ }^{34}$ a koje ćemo ovdje podvrgnuti kritičkoj raščlambi.

Iz samog pisma nedvojbeno je da je autor fakultetski obrazovana osoba. Pismo je naslovljeno „Dragi Hans“, iza čega se po svemu sudeći krije poznati Pavelićev pouzdanik iz vremena poslije sloma NDH - časnik HOS-a Ivan (Ivica) Krilić, ${ }^{35}$ dok je potpis u rukopisu „AS“, što je poznati Pavelićev pseudonim, tj. akronim od Ante (Antonio) Serdar kojim se služio i u kasnijim tekstovima. Iako je pismo naslovljeno na Krilića, ono se odnosi i na preostalo vodstvo u Austriji. U prvom redu na Sušića kao „najstarijeg“, ${ }^{36}$ a potom i na Frkovića. Iz samog pisma vidljivo je da je ono nastalo, među ostalim, i kao odgovor na Sušićevo pismo ili upite o kojima je Krilić ranije obavijestio Pavelića prenijevši mu i Sušićevo mišljenje

32 HR-HDA-1561. SDS RSUP-a SRH, 013.2.25a, Istražni zapisnik Drage Duvnjakovića (Drago Jilek) od 8. ožujka 1950., 11.

33 HR-HDA-1561. SDS RSUP-a SRH, 013.2.25a, Istražni zapisnik Drage Duvnjakovića (Drago Jilek), $11-12$.

34 Pismo ima 4 strojopisne stranice, pisano je korijenskim pravopisom te ne sadrži dijakritičke znakove. Citirane dijelove donosimo u izvornom obliku uz dodane dijakritičke znakove. Pismo se nalazi u autorovu posjedu.

35 Ivan Krilić, (Višegrad, 1921. - Rim, 2010.), ustaški časnik. Studirao pravo, aktivan u katoličkim organizacijama. Član ustaškog pokreta od 1938. Poslije uspostave NDH ustaški je logornik u Višegradu. Prelazi u Zagreb u Ustašku vojnicu kao poručnik pri GUS-u. Na vojnoj je izobrazbi zajedno s Pavelićevim sinom Velimirom, u njemačkom vojnom učilištu u Stockerau 1943. Povlači se prema Austriji i prelazi u Italiju. Među ostalim, zadužen je za prebacivanje osobnih stvari obitelji Pavelić iz Austrije u Italiju. Kod jednog prelaska u Austriju, u siječnju 1948., uhićen je i kažnjen s tri mjeseca zatvora jer nije imao odgovarajuće isprave. Tko je tko u NDH, 208. Srećko Rover donosi popis konspirativnih imena sudionika akcije, među kojima se „Hanz“ i „Hans“ odnose na Ivicu Krilića. Srećko Rover, Svjedočanstva i sjećanja, Zagreb, 1995., 212 i 393.

36 Poslije sastanka bivših visokih dužnosnika NDH u Spittalu (na Dravi) 20. rujna 1945. godine, Sušić je „smatran najstarijim od ministara i čovjekom oko kojega se svi poslovi imaju kretati“. HRHDA-1561. SDS RSUP-a SRH., Dosje Božidara Kavrana, 18. Katalinić preuzima netočnu tvrdnju da je Sušić izabran „na sugestiju dr. Pavelića“. K. Katalinić, Od poraza do pobjede, 58. Naime, sudionici sastanka u to vrijeme nisu znali gdje se nalazi Pavelić niti su imali ikakvih veza s njime. 
vezano za katastrofalan završetak akcije. ${ }^{37}$ Sukladno tomu, ne radi se samo o prvim dostupnim Pavelićevim porukama Sušiću poslije saznanja o propasti akcije već i o prvom poznatom Pavelićevu pismu u kojem govori o akciji dok se još nalazio u Italiji. Štoviše, s obzirom na dosadašnji stupanj istraženosti, može se tvrditi da Pavelić u ovom pismu iznosi svoj najjezgrovitiji pogled kako na samu akciju tako još više na okolnosti djelovanja poslije njezine propasti. Pri tome naravno ne treba smetnuti s uma i moguću namjeru da i kroz ovo pismo svoju vlastitu ulogu u akciji post festum prikaže u drugačijem svjetlu. Upravo zbog svega navedenog, jasno je da se radi o nezaobilaznom izvoru kod daljnjih istraživanja i prosuđivanja o Pavelićevu stavu, odgovornosti i ulozi u akciji „Deseti travnja”.

U vrijeme nastanka pisma Pavelić se nalazio u svom posljednjem skrovištu na talijanskom tlu - prije odlaska u Argentinu - u isusovačkom samostanu Posillipo u Napulju, dok se Krilić vjerojatno nalazio u Rimu. Ta okolnost nije bila osobita poteškoća koja bi priječila njihov osobni susret, međutim činjenica da se komunikacija održavala pismenim putem govori prije svega o Pavelićevoj strogoj konspiraciji prvenstveno radi skrivanja mjesta njegova boravišta, ne samo kada se radi o vlastitim pouzdanicima (kao u ovom slučaju) nego čak i o članovima vlastite obitelji.

Pismo nije datirano, međutim Pavelić navodi da je preko radija ${ }^{38}$ „pratio od početka dogadjaj“. U određivanju vremena nastanka pisma pomaže nam dio u kojem Pavelić navodi: „Prekojučer je razprava prekinuta na osam dana na zahtjev jav. (javnog, op. a.) tužitelj(a), da bi mogao proširiti obtužnicu na njega (Kavrana, op. a.) i na Sabolića. “39 Ako znamo da se prekid rasprave dogodio 17. srpnja, onda nije teško zaključiti da Pavelić piše dva dana kasnije, tj. 19. srpnja. Pogrešno navodi da je Kavran uhvaćen "naknadno, nakon što je već razprava započela“. ${ }^{40}$ Razlog tomu vjerojatno leži u činjenici da u tom trenutku nije mogao znati točan datum Kavranova uhićenja, dok je službeno objašnjenje (koje je i Pavelić čuo preko radija) bilo da se suđenje prekida zbog proširenja optužnice i na Kavrana.

Međutim, jedan od ključnih razloga zbog kojeg se čekalo s početkom montiranog sudskog procesa do 12. srpnja, iako je Kavran uhvaćen 3. srpnja, je planirana i na koncu neuspješno izvedena otmica Mate Frkovića u noći 7.

\footnotetext{
37 „Naravno da je ciela stvar vrlo tragična, i razumljivo mi je, da ju Onkel (Lovro Sušić, op. a.) smatra katastrofalnom, nu zato se ipak nesmije očajati.“ (Pismo AS - Hansu, 1.)

38 Josip Hrnčević, koji je bio javni tužitelj na procesu, navodi: „Cijeli tok rasprave prenosio je RadioZagreb.“Josip HrnčEvić, Svjedočanstva, Globus, Ljubljana, 1984., 112.

39 Pismo AS - Hansu, 1.

40 Pismo AS - Hansu, 1.
} 
na 8. srpnja. ${ }^{41}$ Frkovićevom otmicom htjelo se predstojećem procesu dodatno dati na težini i zbog činjenice da se radilo o bivšem visokom dužnosniku vlade $\mathrm{NDH}$ i ustaškog pokreta. S obzirom na zadane ciljeve koje je planirani proces u nastalim okolnostima trebao ispuniti, bivši ministar unutarnjih poslova NDH na optuženičkoj klupi u tome bi uvelike doprinio. Naime, kako je Frković „bio unutar te akcije zadužen za vanjskopolitičke veze, trebali su ga kao krunskog svjedoka putem kojega bi nastojali dokazati da je akcija 'Deseti travnja' doista bila tek privjesak američke obavještajne službe“.42

\section{b.) Izdaja ili UDB-ina sreća}

Poslije navedenih uvodnih rečenica Pavelić iznosi svoje viđenje mogućih uzroka neuspjeha akcije:

„Boži (Kavranu, op. a.) nije bilo za pomoći, jer absolutno nije htio poslušati savjeta i pouzdavao se je u stanovite ljude. Težko je griešiti dušu, nu onaj njegov suradnik, u koga se je toliko pouzdavao, možda je u velike krivcem nesreće, ako ne izravno, a to svakako neizravno, i sigurno su njegovi savjeti i obmanjivanja Božu uveli u pogrješno prosudjivanje mnogih stvari. Ako sam dobro razabrao iz Božkova (Franjo Bušić, ${ }^{43}$ op. a.) pisma, i Alt. (Eugen Altman, op. a.) bi bio imao počiniti izdaju." ${ }^{4}$

U novijim istraživanjima o razlozima i vremenu infiltracije jugoslavenskih tajnih službi unutar same akcije navodi se kako se radilo više o sreći nego osobitoj sposobnosti jugoslavenskih službi. Naime, „UDB-a nije ovladala akcijom zahvaljujući izdaji iz emigracije, nego tek nakon slučajnog kontakta trojke (prva ubačena skupina, op. a.) s udbašem koji je lutao Papukom“. U suprotnom ne bi dopustili da se trojka „toliko vremena nesmetano kretala unutar Jugoslavije, već bi

41 Svjedočanstvo Mate Frkovića o pokušaju otmice vidi u: V. Ni kolić, Pred vratima domovine, II, 181.

42 K. Katalinić, Od poraza do pobjede, 74 . O analizi pozadine procesa vidi stranice $67-80$.

43 Franjo (Boško) Bušić, rođen 1908. god. u Gorici, Ljubuški. Pripadnik predratne ustaške emigracije i osoba od Pavelićeva povjerenja. Na popisu ustaša na Liparima navodi se kao Bušić Frano. B. Krizman, Ante Pavelić i ustaše, 564 i 557.

44 „To me nebi ni najmanje iznenadilo, nu odatle bi trebalo povući konsekvence, te bi se Onkel (Lovro Sušić, op. a.) i Ana (Mate Frković, op. a.) morali dobro zaštiti(ti), budući je on barem sve do sada bio u njihovoj neposrednoj blizini.“ (Pismo AS - Hansu, 1.) Kavran navodi da je Altman bio Sušićev blagajnik, a o njegovoj ulozi u pothvatu u istrazi je izjavio: „Ja sam obavještajna pitanja i upute za organiziranje spomenute obavještajne mreže, koju sam ja nazvao 'Veza Nikolić', dobio od Gece Altmana. Geco Altman s naše je strane održavao vezu s američkom obavještajnom službom i od nje je dobivao takve sugestije. On se naime povezao u Salzburgu sa grofom Meranom, koji je radio za američku obavještajnu službu i preko tog Merana radio je Geco Altman s naše strane. Neko vrijeme tokom 1947.g. Altman je i stanovao na posjedu tog grofa." HR-HDA-1561. SDS RSUP-a SRH., Dosje Božidara Kavrana, 81. 
je bili uhitili odmah nakon prijelaza granice, kao što se to događalo sa svim drugim skupinama koje su ušle nakon trojke “. ${ }^{45}$ Poslije hvatanja prve skupine i pristanka na suradnju Ljube Miloša, ${ }^{46} \mathrm{UDB}-\mathrm{a}$ je preuzela potpuno upravljanje akcijom.

Kad je riječ o drugom pravcu u kojem Pavelić traži uzroke neuspjeha to je „onaj njegov suradnik, u koga se je toliko pouzdavao, možda je u velike krivcem nesreće, ako ne izravno, a to svakako neizravno". S obzirom na to da Pavelić ne navodi njegovo ime, ostaje nam pretpostavljati. Naime, Kavran u istrazi navodi da je u tom trenutku „sve svoje nade polagao u akciju koju je otpočeo Drago Jilek" te je samo čekao Jilekov povratak iz Italije u Austriju. ${ }^{47}$ Međutim, je li Pavelić mislio na Jileka ili na nekog drugog od Kavranovih suradnika u Austriji u ovom trenutku nije moguće tvrditi.

U pismu Pavelić navodi da sada "treba sa radom nastaviti“ te iz svega izvući dvije pouke: „1/ da su neke stvari bile mnogo preuranjene i $2 /$ da se je radilo sa dosta neopreza, te da treba u buduće postupati sa najvećim oprezom, ne samo unutra nego i vani, ako se neće izložiti pogibelji ljude. “48 Ističe kako unatoč katastrofalnom završetku „dogadjaj nemože ni malo umanjiti vriednost stvari, već će naprotiv biti najboljim dokazom rada, aktivnosti i duha“ te će „u domovini imati i najveći odjek“. Pri tome povlači paralelu s odjekom „što ga je svojedobno proizveo tako zvani lički ustanak ${ }^{\text {“ }}{ }^{49} \mathrm{Uz}$ bitnu razliku što je kod

45 „Uostalom, ne postoji nikakav opravdan razlog zbog kojeg bi UDB-a hotimično (istaknuo K. K.) dopustila da se trojka toliko vremena slobodno kreće po Hrvatskoj, ukoliko ju je mogla ranije otkriti i uhititi.“ K. Katalinić, Od poraza do pobjede, 67. „Sve je započelo sredinom srpnja 1947. g. kada su se sa suradnikom osječkog odjela OZN-e, koji je tumarao Papukom, povezala trojica ilegalaca." Bogdan Krizman, Pavelić u bjekstvu, Globus, Zagreb, 1986., 177.

46 „Među hrvatskim izbjeglicama našao se je i Ljubo Miloš. Njemu je predbacivao dr. Draganović njegove postupke u logoru Jasenovac, te mu reče, da njegovo mjesto nije u emigraciji, nego u šumi. Miloša su ti prijekori i predbacivanja pogodila, i on se doista odlučio na povratak u Hrvatsku.“ Mate Frković, Svaki sa svojom dramom: jedno svjedočanstvo. Iz mojih političkih doživljaja, Hrvatska revija, 1984., sv. 3., 483.

47 HR-HDA-1561. SDS RSUP-a SRH., Dosje Božidara Kavrana, 62.

48 „Nenadoknadiva je šteta, kako rekoh, ljudi, koji su stradali, nu baš obzirom na okolnost, da je stvar bila u mnogo čemu preuranjena, za stvar je manja šteta, nego da j(e) išla na ovaj način dalje, i da se je nesreća dogodila u jednom kasnijem, odlučnom času, kada bi bilo moglo biti sve izgubljeno, i kada bi katastrofa u brojčanom pogledu bila mogla biti strašnija od one lavantalske (sinonim za događaje koje danas poznajemo pod nazivom Bleiburška tragedija i križni put, op. a.) od 1945.“ (Pismo AS Hansu, 1)

49 I slabije upućenom čitatelju bode oči Pavelićev govor o "takozvanom ličkom ustanku“. U prvom redu jer je izraz „lički“ za Pavelića, Krivopućanina, previše uopćena odrednica. A pogotovo strši pridjev „takozvani“, osobito u trenutku kad je repriza doživjela katastrofu poznatih razmjera. Međutim, naziv „lički ustanak“ korišten je i u vodećim publikacijama ustaško-domobranskog pokreta još u međuratnom razdoblju. Vidi: Lički ustanak pred sudom, Hrvatski domobran, god. IV. br. 110. (Buenos Aires), 22. srpnja 1933. s. 2-3. 
ličkog ustanka „stvar bila proračunana i na taj efekt tempirana, pa su žrtve bile mnogo manje, što ovdje na žalost nije slučaj, nu u stvari je efekt isti“"50

\section{c.) „Podor kroz visoku kapiju“ ili o vezama sa zapadnim dužnosnicima}

Vodstvo u Austriji nastojalo je uspostaviti veze sa zapadnim saveznicima, odnosno u prvom redu s američkom stranom. Također, postojala je svijest da „od svih tih veza sa ovdašnjim Amerikancima ne može biti mnogo koristi i neće se moći ništa jačeg i stvarnijeg učiniti za našu stvar, jer da su to manje više sve izvršni organi koji imadu samo provoditi naloge koje primaju odozgo“. Potrebno je uspostaviti vezu „sa odlučujućim faktorima političkog života, odnosno Ministarstva vanjskih poslova, vojske i mornarice u samoj Americi“.51

O vezama vodstva akcije „Deseti travnja“ sa zapadnim obavještajnim službama svjedočanstvo je ostavio Mate Frković koji je unutar akcije bio zadužen za pitanje tih veza. Frković navodi kako je inicijativa došla s američke strane zbog zaoštravanja odnosa između SAD-a i Jugoslavije. Američku stranu je prvenstveno zanimalo „koliko, po prilici, može biti Hrvata u šumi?“ Frković je odgovorio „da ima nekoliko skupina na raznim mjestima i da se oni stalno bore protiv partizana. Amerikanci su tu činjenicu primili pozitivno, a to je za nas bio poticaj za što intenzivnije okupljanje Hrvata za nastavak borbe." 52

Frković se $s$ američkim predstavnicima sastao nekoliko puta u jesen i zimu 1947. godine te u prvoj polovici 1948. godine u Zell am Seeu, Bad Gasteinu i Salzburgu. ${ }^{53}$ Američki obavještajci tražili su podatke o stanju u Jugoslaviji koje su stvar toliki vanjski faktori podupiru, doprieti i u najzabitniji kutić, a to naravno neće duh oslabiti nego ojačati." (Pismo AS - Hansu, 1)

51 HR-HDA-1561. SDS RSUP-a SRH, 015.7-11., Zapisnik saslušanja Vladimira Sabolića, 14 - 15.

52 „Oni su odlučili pomoći našu akciju i uručili nam razne vrsti instrumenata pa, ako stvar bude tekla povoljno, pošiljke će se povećati. Osim toga, Amerikanci su bili zainteresirani za Makedonce, pa sam se sastao u nekoliko navrata s Vančom Mihajlovom na Bodenskom jezeru. $U$ razgovoru, on je bio vrlo rezerviran, jer nije vjerovao u uspjeh.“ M. Frković, Svaki sa svojom dramom, 483 - 484. Treba spomenuti da je i Pavelićeva obitelj za vrijeme skrivanja u Austriji i Italiji održavala vezu s Mihajlovim.

53 „Ja sam smatrao, da nam se je pružila izvrsna prilika, da pojačamo našu borbu protiv srbokomunističkih zločinaca u domovini. Naši razgovori s Amerikancima urodili su plodom, jer je posredničkim putem t.j. preko Austrijanaca, bilo primljeno nekoliko radio-aparata za davanje i primanje vijesti, te nešto oružja. Za baratanje s tim aparatima bili su upriličeni tečajevi, koji su bili održavani na nekoliko mjesta." M. FRKović, Nepoznate stranice iz poslijeratnog djelovanja, Hrvatska revija, München-Barcelona, rujan 1971., sv. 2.-3., 296. „Sa sigurnošću se može zaključiti samo to da su Amerikanci nastojali iskoristiti ustašku emigraciju za dobivanje korisnih vojnih informacija, a ustaško je vodstvo nastojalo zajednički protukomunizam i strah od širenja zone utjecaja SSSR-a iskoristiti za obnovu NDH i rušenje Jugoslavije.“ Z. RADELIĆ, Križari-gerila u Hrvatskoj 1945.-1950., 51. 
trebali dostaviti križari. Iz Frkovićeva teksta proizlazi kako su hrvatski emigranti predavali takve obavijesti američkim obavještajcima koji su se svakako htjeli prije pružanja ozbiljnije pomoći uvjeriti u postojanje jačih križarskih odreda u Jugoslaviji. U jednom od razgovora bilo je riječi o prvoj rati „za pomoć“ u iznosu od 100.000 dolara, uz pitanje jesu li Hrvati „u stanju dignuti revoluciju u Jugoslaviji i izdržati bar 8 dana?" Frković na to pitanje nije „imao konkretnog odgovora“ te se „obratio na Božu Kavrana, koji mi je dao nacrt šuma“ koji je potom predan Amerikancima ${ }^{54}$ Međutim, Frković ne navodi što je u spomenutom nacrtu stajalo.

$S$ druge strane, Sabolić navodi kako je u veljači 1948. razgovarao s Frkovićem koji mu je pričao o svojim razgovorima $s$ američkim predstavnicima te da je na pitanje o ustanku u zemlji „on (Frković, op. a.) niječno odgovorio i da bi se moglo, ali da bi ustanak bio potpuno svladan i mi potpuno uništeni“. Na jednom sastanku dobio je ponudu ,jednu veću novčanu potporu, mislim oko 50.000 dolara, ako ide u Hrvatsku u svrhu da sudjeluje u vodstvu oko organiziranja otpora. Frković mu je rekao, da će ići kad svrši tamo poslove."“5s

Kad je riječ o bivšim visokim dužnosnicima Amerikancima, „ni sam Poglavnik nije im bio toliko mrzak, koliko Dido Kvaternik i Maks Luburić. Oni su za sve njih bili crvena krpa, i nisu željeli, da bi oni dobili kakovu ulogu u pokrenutoj akciji.“ Kontakti su prekinuti nakon predaje posljednjih podataka iz domovine (koje je ustvari sastavila UDB-a, op. a.) „pod izlikom“ čekanja odgovora iz Washingtona. Također, par mjeseci prije tragičnog kraja akcije Frković je Amerikancima „predao memorandum za vladu u Washingtonu“.56

Otprilike u slično vrijeme posljednjih Frkovićevih razgovora s Amerikancima Sušić je pisao suradniku u SAD ističući „da su navedeni naši delegati pripravni razgovarati samo sa vojničkim i političkim faktorima, nikako ne sa jednostavnim obavještajcima, pa bili i u višem rangu, jer mi nećemo ničije službe nego samo suradnju, a najmanje samo vodstvo želi neposredno služiti bilo čijoj obavještajnoj službi“ ${ }^{\text {“57 }} \mathrm{Kad}$ je riječ o temeljnim stajalištima s kojih su vodeći ljudi u Austriji pristupali razgovorima sa zapadnim predstavnicima, Sušiću je nedvojbeno od ranije bio poznat i Pavelićev stav o tom pitanju. Naime, Pavelićeve upute bile su da tamo gdje ona postoji treba održati vezu s Amerikancima uz naglasak da se tek nakon uspostavljanja veze $s$ domovinom može „konkretno raditi“. Nadalje, da nitko ne može nastupati ispred „organizacije ili foruma, već da rade u svoje ime,

54 M. Fr Ković, Nepoznate stranice iz poslijeratnog djelovanja, 297 - 298.

55 Čuvši tu priču, neki Frkovićevi suradnici čudili su se „zašto to Mate nije odmah prihvatio“. HRHDA-1561. SDS RSUP-a SRH, 015.7-11., Zapisnik saslušanja Vladimira Sabolića, 12 - 13.

56 M. Fr ković, Nepoznate stranice iz poslijeratnog djelovanja, 297 - 298.

57 Pismo Lovre Sušića fra Vendelinu Vasilju od 25. 5. 1948. N. Čola K, Akcija Deseti travnja, 429. 
te dok se ne uspostavi veza sa zemljom da nitko nema i neće imati pravo govoriti u ime neke organizacije ili foruma“ 58 To je stav „vodećih ljudi u Austriji koji realno gledaju na stvar i koji ništa ne žele uveličavati“".99 Na Jilekov upit Paveliću preko Kavrana u vezi „obavještajnog rada na suzbijanju OZNE u Italiji i Austriji, a za račun Amerikanaca“, Pavelić je „savjetovao, da se s time što manje zaposlujemo“.60

Sušić je „uhvatio vezu sa Danicom $^{61}$ i preko nje sa pojedinim jačim našim ljudima“ u Americi te da su „odgovori N. Šulentića, dra. Vasilja i S. Grubišića prešli sva naša očekivanja. Javili su nam ujedno i svoj prodor kroz visoku kapiju“, tj. uspostavu veza s krugovima bliskima Washingtonu. ${ }^{62} \mathrm{O}$ tome je pisao $\mathrm{i}$ Luburiću: „Mi ovdje čekamo na razgovor sa opunomoćenikom visoke kapije. Nadamo se, da će se ipak nešto iz toga svariti. “63 Da se radi o SAD-u može se naslutiti iz nastavka Pavelićeva pisma u kojem on iznosi razmišljanja i savjete o vanjskopolitičkom polju daljnjeg protujugoslavenskog djelovanja:

„Činjenica da je došao izaslanik iz W. (Washingtona?, op. a.) može biti od velike važnosti i sada stvar treba vrlo dobro postaviti. Da je došao prije, i da je odnošaj bio baziran na predpostavkama prije nesreće, stvar bi bila mogla izspasti vrlo zlo i nespretno. Ovako sada treba stvar postaviti na posve realnu bazu. U prvom redu treba izaslaniku posve točno prikazati sve što se je dogodilo, i ništa ne zatajiti. (...) Izaslanik je sigurno po njihovoj izvještajnoj službi saznao za dogadjaj, pa se stoga stvar ni nemože tajiti." ${ }^{\text {"64 }}$

58 Ovaj Pavelićev stav poznat je i iz razdoblja njegova međuratnog djelovanja. Primjerice, kod razgovora s talijanskim predstavnikom Robertom Forgesom Davanzatijem naglasio je „ako bi bilo tko došao u ime naše stranke i zatražio bilo kakovu materialnu korist od toga, samim tim činom je desavouiran, jer to nije u suglasnosti s našim principielnim postupkom”. Opširnije u: Ante PAVELIĆ, Doživljaji, II., Zagreb, 1998., 142 - 143; A. PAvelić, Putem hrvatskog državnog prava, ur. Višnja Pavelić, Buenos Aires-Madrid, 1977., 194 - 197; Jere JAREB, Šest dokumenata o prvom dodiru dra Ante Pavelića s talijanskom vladom 1927., Hrvatska revija, god. XX., sv. 4 (80), prosinac 1970., 1165 - 1168 .

59 Jednu od takvih veza s Amerikancima „držao“ je i Drago Jilek kojemu je od strane američkih predstavnika ponuđena materijalna pomoć „ali je Jilek to odbio s time da ne traži ništa dok nema konkretnih rezultata“. HR-HDA-1561. SDS RSUP-a SRH., Dosje Božidara Kavrana, 58 - 59.

60 HR-HDA-1561. SDS RSUP-a SRH, 013.2.25a, Istražni zapisnik Drage Duvnjakovića (Drago Jilek), 12.

61 Mjesečni list hrvatskih iseljenika. Izlazio u Chicagu.

62 N. Čolak, Akcija Deseti travnja, 439.

63 Pismo Lovre Sušića Vjekoslavu Maksu Luburiću od 19. 6. 1948. N. Čolak, Akcija Deseti travnja, 441.

64 Pismo AS - Hansu, 1. Desetak dana poslije predsjedničkih izbora u SAD-u Sušić procjenjuje: „Pobjeda Trumanova ni u koliko ne pogoršava našu stvar niti će promieniti vanjsko-politički kurs dobro i odlučno proveden po Marshallu. Držimo što više, da će Truman, riešen svih obzira prema nasljedstvu Roosevelta, biti sada odlučniji.“ Okružnica od 14. studenog 1948. u: N. ČolAK, Akcija Deseti travnja, 370. 


\section{d.)Zapovjedi ili savjeti - o predstojećem susretu s „izaslanikom“}

Najveći dio pisma odnosi se na dolazak „izaslanika“, prema svemu sudeći američkog. Pavelić niže sedam točaka preko kojih bi se „izaslaniku“ okolnosti događaja prikazale „u pravom svietlu“:

„1/ da je činjenica, da je naša odporna organizacija po vlastitoj pobudi i do sada radali (radila, op. a.) u najvećem razmjeru i to bez ičije pomoći, i što više, unatoč najstrašnijem položaju u kome se svi nalazimo u materialnom i moralnom pogledu, progonjeni od istih Zap. Vlasti i u vječnoj pogibelji hapšenja ${ }^{65}$ i izručivanja sa njihove strane boljševicima. 2/ Da su naši redovi jaki i kompaktni unatoč tomu, da je po Zap. Vlastima izručen veliki broj naših prvaka i justificiran od boljševika, te da je 1945. izručen u Lavantalu cviet naših vojnika i po boljševicima postrieljan. 3/ Da je naš odporni pokret i ovim težkim dogadjajem dokazao svoju najskranju nepomirljivost sa boljševizmom i odlučenost na borbu do najskranji granica. 4/ Da je naš odporni pokret jedini medju svima po boljševizmu zarobljenim narodima, koji radi ne na bezkoristnom beletrističkom radu u inozemstvu, to jest na obijanju savezničkih pragova sa platonskim izljevima protuboljševičkoga opozicionalstva, nego na konkretnom organiziranju odpora i realnom pripremanju oružanih akcija za dani čas. $5 /$ da sa dogadjajem nije zahvaćena čitava organizacija, nego samo jedan njezin dio i to u izvjestnom broju vrhova u domovini, što će se nadoknaditi uz potrebite mjere opreza. 6/ da iz dogadjaja proizlazi, koliko je teška i opasna ova borba is kolikim je pogibeljima skopčan rad na organiziranju odpora. 7/ koliko je prema tome i potrebna pomoć i podpora s njihove strane, da stvar može čim bolje biti provadjana." ${ }^{66}$

U nastavku ističe "stvari, za koje držim da bi ih trebalo uzeti u obzir“. ${ }^{67}$ Prigodom susreta s (američkim) izaslanikom „treba nastojati (...) da nigdje ne naidje na kakove osobnosti ili nesuglasice medju nama, te da uviek vidi samo realan i ozbiljan rad, a nikakove fantastične i nerealne podvige“. Drugim riječima, da Amerikanac ne vidi ono što je do tada bilo vidljivo unutar užeg i šireg vodstva. U suprotnome se to ne bi naglašavalo. Također, kako bi se stvorili uvjeti za sustavnije djelovanje, treba ga uvjeriti - „da uvidi apsolutnu potrebu slobode kretanja sviju nas, i prestanak svake mogućnost(i) progona i izručivanja“. 68

65 Neobična je činjenica da Pavelić govori o "hapšenju“ s obzirom na njegovo poznato ustrajanje na jezičnoj čistoći i činjenici da inače nerijetko piše uhićenje. Štoviše, kao pravniku taj mu termin nije nimalo neobičan. „Hapšenje“ koristi i u članku objavljenom dvije godine kasnije: „Hapsili su i ubijali one, koji se nisu mogli braniti.“ Ante SERDAR, Značenje i uloga emigracije, Hrvatska, Buenos Aires, 17. ožujka 1951., god. V., br. 6. (82.), 1.

66 Pismo AS - Hansu, 1 - 2.

67 Pismo AS - Hansu, 3.

68 Pismo AS - Hansu, 2. 
Sada, poslije propasti akcije i hvatanja Kavrana, Pavelić navodi koga smatra članovima užeg vodstva: „Treba nastojati da on (izaslanik, op. a.) dodje u doticaj samo sa nekolicinom, (Onkelom, ${ }^{69}$ Matom, ${ }^{70}$ Mekom, ${ }^{71}$ popom J. ${ }^{72}$ i Tobom) i da absolutno nikakov širi krug ne sazna za njega, napose ne one razne osobe koje su do sada gore u Aus. (Austriji, op. a.) bile oko njih." ${ }^{\text {"73 }}$

Osobito je zanimljiv dio iz kojeg se vidi Pavelićevo nemalo pouzdanje u Krilića, što je tim zanimljivije ako pretpostavimo da su pismo kasnije čitali gore navedeni članovi vodstva koji su u formalnom hijerarhijskom smislu bili daleko iznad Krilića. Međutim, postajala je i svojevrsna neformalna hijerarhija:

„Meni bi bilo mnogo stalo do toga, da Ti dodješ u doticaj sa izaslanikom još ovdje, prije nego se sastane s njima, a eventualno da ga upoznaš i sa p. Jolom. Ti mu možeš bez daljnjega reći, da stojiš u neposrednoj vezi sa, kako se je ono znalo u poštenim i nepoštenim namjerama govorit, „najvišim“ mjestom; to naravno na nenapadan način i ako vidiš potrebu i korist od toga. Ako bi spomenuo, da bi eventualno htio doći u osobni doticaj, treba reći, da će se upitati, i da bi odgovor mogao stići nakon izvjestnog vremena, nu da bi to imalo smisla samo onda, ako se stvar izmedju njega i vas razvija i postavi na konkretnu bazu u gore navedenom smislu. ${ }^{\text {"74 }}$

Lovro Sušić.

70 Mate Frković.

71 Meho (Mehmed) Mehičić, odvjetnik i političar (Bosanski Petrovac,? 1904. - Salzburg, 1967.). Gimnaziju završio u Sarajevu, a studij prava s doktoratom u Zagrebu. Nakon uspostave NDH imenovan je podžupanom velike župe Dubrava u Dubrovniku. U studenome 1943. premješten je na istu dužnost Velike župe Hum u Mostar, a početkom svibnja 1944. imenovan je ministrom obnove opustošenih krajeva, na kojoj dužnosti ostaje do svibnja 1945. S ostalim članovima Vlade NDH 6. V. 1945. napušta Zagreb. Odlazi u izbjeglištvo u Austriju, u Klagenfurt, a potom u Salzburg, gdje ostaje do kraja života. Surađivao je u salzburškom Caritasu, koji se pod vodstvom Vilima Cecelje brinuo za mnogobrojne izbjeglice iz Hrvatske. Tko je tko u NDH, $263-264$.

72 Jole (Josip) Bujanović, vojni dušobrižnik i veliki župan (Zavalje kraj Bihaća, 1914. - Adelaide, 2001.). Prije rata svećenik u Lici, uoči rata djelovao je među hrvatskom mladeži u rodnom kraju, a za vrijeme NDH dušobrižnik je u domobranskim i ustaškim postrojbama. Sudionik je obrane Gospića od partizana u svibnju 1943. Ostaje u Lici kao duhovnik 4. ustaškog djelatnog zdruga do jeseni 1944., kada dobiva i čin ustaškog bojnika-duhovnika. U ožujku 1944. imenovan je upraviteljem, a u prosincu velikim županom Velike župe Lika i Gacka. U Zagrebu 25. IV. 1945. podnosi izvješće predsjedniku Vlade N. Mandiću u kojem, među ostalim, predlaže vođenje gerilskog rata u Lici. Iste godine povlači se u Austriju, potom u Italiju, a poslije u Australiju. God. 1946., zajedno s D. Žankom, predvodio pjevački zbor hrvatskih emigranata u audijenciji Papi. Aktivan u hrvatskim emigrantskim organizacijama. Tko je tko u NDH, 56.

73 Pismo AS - Hansu, 2.

74 Pismo AS - Hansu, 2. 
Vezano za buduće djelovanje „odpornog pokreta“, poslije rješenja problema „slobode kretanja“ s izaslanikom treba „uglaviti, da se sada, dok se u domovini ne začepi nastala rupa, pristupi (...) dovršenju organizacije boraca i njihovo i ako nevidljivo postrojenje $\mathrm{u}$ jedinice (ne formalno na okupu, nego bezprostorno gdje se tko nalazi)“75 Kad je riječ o načinima budućeg rada, „dielim Tvoje mišljenje, da se uperi rad na promičbu i organiziranje u inozemstvu, a u domovini da se momenta(l) no ograniči na promičbu“. U tu svrhu potrebno je s izaslanikom ,izhoditi bezuvjetno jednu, makar i čednu krugovalnu postaju, da se mogu davati viesti i vršiti promičba, a s druge strane treba naći mogućnosti, da se u domovinu ubacuje tiskani promičbeni material, što bi uz malu pomoć izaslanikovih bilo moguće provesti““.76

Kod buduće organizacije djelovanja prema zemlji, „nije nikako uputno stvarati u domovini jedan cieli forum vodstva, nego nastojati, kako i Ti primjećujes, ubacivati pojedince ili najmanje grupice, koji bi odlazili i dolazili, tamo osnivali isto tako malene grupice, izvršili eventualne im date zadaće, odnosno povjerili izvršenje grupicama po njima stvorenim. Tako je u ostalom radjeno i prije 1941. pa i ako je tu i tamo bio koji slučaj stradanja, nije se mogao dogoditi ovakov debakl kao ovoga puta." 77

Među ostalim, vjerojatno zahvaljujući i činjenici da je početak suđenja pratio preko radija, Paveliću je bilo jasno da su mnogi sudionici akcije znali puno više od onoga što je bilo potrebno za izvršenje povjerenih im zadaća: „Treba osobito paziti na to, da oni, koji po takovom poslu odu, nemaju nikakova konkretnoga znanja o osobama u inozemstvu, odnosno o njihovom kretanju, o njihovom mjestu boravka i o njihovim vezama. ${ }^{\text {“78 }}$

$\mathrm{Na}$ koncu, kad je riječ o izaslaniku, Pavelić naglašava kako je potrebno nedvosmisleno ga posebno „upozoriti“ da ni on (Pavelić) ni njegovi sljedbenici ne odustaju od svoga temeljnog političkog postulata: „Da nismo ni uz koju cienu spremnipoduprijetistvaranjebilokakove Jugoslavije, ni kraljevskeni republikanske, ni totalitarne ni demokratske, nego da ćemo se boriti i da radimo isključivo za državnu nezavisnost bez obzira na to koje će osobe u njoj vladati (naravno osim komunista), a isto tako da ćemo se boriti proti svakoj vrsti Jugoslavije. ${ }^{\text {“79 }}$

„Treba ga upozoriti (izaslanika, op. a.), da smo uslied nemogućih prilika u Europi morali veliki broj ljudi odpremiti u J. A. (Južnu Ameriku, op. a.), i da nam se omogući, da te ljude pravodobno stavimo u gibanje, to jest da već sada izvršimo za to potrebne mjere.“ (Pismo AS - Hansu, 2).

76 „Sad će bezuvjetno uslied dogadjaja nastati kroz neko vrieme u domovini praznina, nu za kratko vrieme će se sigurno nadati prilike, da se obnovi i konkretni rad, naravno sa mnogo više opreza i sa mnogo manje lahkovjernosti." (Pismo AS - Hansu, 2).

77 Pismo AS - Hansu, 2.

78 Pismo AS - Hansu, 2.

79 Pismo AS - Hansu, 2 - 3. 
Izaslanik je stigao u Italiju i „ide preko ovdješnjeg njihovog 'Stelle“" ${ }^{\text {'80 }}$. Međutim, treba paziti da razlozi njegova putovanja ne dođu i do onih nepoželjnih:

„Treba ga u obće upozoriti na najveći oprez u doticaju sa osobama koje su izvan najužeg kruga, naravno u koliko se tiče ove naše stvari. Povrh svega ga treba upozoriti na djelatnost Ozne, a i na djelatnost Srba odnosno tako zvanih jugoslavena, za koje se nikada ne zna u čijoj su službi. ${ }^{\text {“81 }}$

Krilić također treba o svemu navedenom u pismu „točno informirati“ Sušića te „njemu i ostalima gore duh podići prije nego dodju u doticaj sa izaslanikom. (...) Svakako me obaviesti o daljnjem razvitku, nastoj da se dobro promisli koga bi se poslalo kao izaslanika s naše strane, ako do toga dodje, i gledaj da se stvar čim bolje instradira." ${ }^{\text {" } 2}$

\section{e.) „Biti će interesantan daljnji razvitak“}

U drugom dijelu pisma Pavelić se osvrnuo na započeti montirani sudski proces uhvaćenim pripadnicima akcije, na njegovu pozadinu i neke od ciljeva koje se procesom nastojalo ostvariti. Ocjenjuje kako optuženici iznose „takove stvari, o kojima ovi u glavnom nisu mogli imati znanja, nu neprijatelji su ih znali po svojoj špionaži i od ev. (eventualnih? op. a.) izdajica, pa su obtužene prislili da te izkazuju“. Na samom suđenju je „sve upereno proti vatikanu, pa i izričito proti samom Papi, ${ }^{83}$ dočim se talijane ni ne spominje. Spominje

80 „Stelle“ na njemačkom, među ostalim, znači mjesto, služba, ispostava. Iako se Pavelić tada nalazio u Italiji, iako on i njegov sugovornik govore talijanski, on ovdje oznakom "Stelle“ označava Amerikance iz nekoliko razloga. U prvom redu jer to odgovara pravilima konspiracije. Nadalje, iz pisma je vidljivo da Krilić od ranije zna da se radi o američkom izaslaniku. Također, ne manje važno, Krilić je bio na njemačkoj vojnoj izobrazbi (zajedno s Pavelićevim sinom Velimirom) u Stockerau, zbog čega mu je ta njemačka oznaka dobro poznata. Na koncu, izraz 'Stelle' Pavelić je u istom razdoblju, za vrijeme skrivanja u Italiji, koristio u pisanju Doživljaja (u dijelu koji se odnosi na razdoblje NDH) kao sinonim za obavještajnu službu: „...osoba koje su se već nalazile u službi neke njemačke obavještajne "Stelle“ (postaje).“ Ante PAvelić, Doživljaji. Kako sam osnovao Nezavisnu Državu Hrvatsku, Zagreb, 2015., 170. Treba naglasiti kako je ovdje citirani naslov (s podnaslovom kojega u izvornom rukopisu nema!) zapravo svojevrsno kolaž izdanje III. i IV. dijela Pavelićevih Doživljaja, a cjeloviti tekst IV. dijela Doživljaja tek treba objaviti.

81 Pismo AS - Hansu, 3.

82 Pismo AS - Hansu, 3.

83 „Naravno većinom stvari izkrivljene, kao onu, da je Papa prigodom primanja u audienciju ust. (ustaških, op. a.) zločinaca izričito ih podstrekavao na zločinački rad proti Jugoslaviji i u tu im svrhu podielio blagoslov. (...) Jedan je od obtuženih izkazao, da je prisustvovao u Klagenfurtu sastanku nadb. Šarića (nadbiskup vrhbosanski Ivan „Evanđelist“ Šarić) i Kard. Initzera (Theodor Innitzer, bečki nadbiskup i kardinal, op. a.), gdje se je raspravljalo o podunavskoj federaciji i rušenju Jugoslavije i slične stvari. Vatikan će naravno sam moći prosuditi, da se radi o montaturi." (Pismo AS - Hansu, 3). 
se 'izvjestne strane države', koje da su to ubacivanje vršili u svrhu špionaze.“ Mogle bi doći „u obzir odnosne am. (američke, op. a.) osobe, nu ni tu nema ništa konkretnoga, odnosno nisu poznata nikakova imena“" ${ }^{84}$ Kao primjer da su optuženike „vjerojatno mučili, te i na razpravi moraju izkazivati što im je propisano, od straha pred daljnjim mučenjima“, Pavelić navodi Miloševu izjavu „da sam ja (Pavelić, op. a.) stanovao kod puk. Gjala (Džala, op. a.), i da sam im govorio, kako treba potući sve srbe u Hrvatskoj“. 85

U završnom dijelu pisma Pavelić iznosi svoja promišljanja s obzirom na novonastale okolnosti u kojima se našla jugoslavenska komunistička vlast poslije objave rezolucije Informbiroa te ističe i moguće posljedice s kojima, po njegovu mišljenju, treba računati. Na međunarodnom planu „dogadjaji i prilike postaju sve napetiji“ i stanje se "neće moći još jako dugo ovako održati. Nemogu vjerovati, da je Rusija već toliko spremna, da bi joj konveniralo već sada dotjerati mak na konac, nu tko zna što se sve može dogoditi, a što bi moglo stvar požuriti.“ S druge strane, u "Jugovini“ se nedvojbeno „radi isključivo o tome, da se skine glava osobno Titu“. Optužbe iz Moskve na račun Tita i KPJ su „jedna obična boljševička formula, koja se primjenjuje stereotipno na svakoga, koga se hoće likvidirati“" ${ }^{86}$

Sukob Tito - Staljin, Pavelić je objasnio sljedećim riječima:

„U ovom se slučaju radi o tome, da nemogu u boljševičkom kompleksu obstojati dva maršala i dvije vodje komunizma, pa jedan mora ići, a taj jedan nemože naravno biti Stalin. Tito je čovjek nepismen, mali sitni duh, pa mu je veličina udarila u glavu, kao i svim malim ljudima, kada ih kakova zgoda na površinu izbaci, a o čemu smo se imali prilike toliko puta osvjedočiti. ${ }^{87}$ (...) I Tito je bio dobar kada je trebalo paliti sela i ubijati ljude, ali kada je postao maršal i diktator Jugoslavije, umislio si je, da mu nema premca. Uveo je svoj podpuno

„Kada se govori o špionazi, onda to nije nikakovo kompromitiranje, jer to svi rade, i to se nikada ne uzima kao neprijateljski čin, jer je špionaza stekla medjunarodno pravo državljanstva i kavalirštine kod sviju država." (Pismo AS - Hansu, 3).

85 Pismo AS - Hansu, 3. Usp. HR-HDA-1561. SDS RSUP-a SRH., 015.7/12. Sudski spis s rasprave u procesu protiv Ljube Miloša i dr. Stenografski zapisnik s glavne rasprave. Svjedočanstvo Ivana Prusca o mučenju jednog od uhvaćenih križara, Vinka Dundovića, vidi u: N. ČolaK, Akcija Deseti travnja, 150.

86 „Tako je uviek glasila svaka obtužba proti svim generalima i stranačkim prvacima u Rusiji, kojih se je Stalin htio rješiti, jer su njemu bili nepoćudni, pa proti istome Trockiju.“ (Pismo AS - Hansu, 4).

$87 \mathrm{Na}$ ovom mjestu kao primjer iz prošlosti Pavelić u jednoj rečenici spominje ministra Antu Vokića, očito aludirajući na tzv. puč Lorković-Vokić: „Medju inim tolikim slučajevima dosta je sjetiti se slučaja našeg željezničara, koji je bio izvrstan činovnik sarajevskoga željezničkog ravnateljstva, nu kada je postao ministrom prometa, a onda još i ministrom oružanih snaga, (Vokić) sila mu je pameću zavrtila.“ (Pismo AS - Hansu, 4). 
osobni režim, i podigao se na piedestal veličini, tako da se i sam Stalin gubi u njegovoj sjeni. Medju svim komunističkim eksponentima, što stoje na čelu u novim boljševičkim nacijama u iztočnoj i jugoiztočnoj Evropi nije ni jedan pokusao ići tim putem, a za šefove Ukraine, Biele Rusije i sličnih država gotovo se i nezna. Naravno da se to nije moglo dugo podnašati, a napose to ovi šefovi nisu mogli više trpiti. Osim toga on si je u svojoj veličini bio preduzeo, da likvidira i Albansku i bugarsku državnost, te da načini 'veliku i moćnu' Jugoslaviju, baš onako, kako je to priželjkivao i kralj Aleksandar. Reakcija Albanije, Bugarske pa i Madjarske vrlo su značajne, i jasno karakterišu cielu stvar. Titov odpor proti osudi Kominforma svjedoči samo to, da je osuda nepromjeniva, i da nema drugoga izlaza, nego se pokoriti i kapitulirati, a to nije lahko učiniti. ${ }^{\text {" } 88}$

Pavelićeva predviđanja o budućem položaju Jugoslavije i Tita nisu bila optimistična - i kako danas znamo - ni u skladu s njegovim očekivanjima. Naime, o „prelazu Jugoslavije u protivni tabor nemože biti ni govora“, a također je nezamislivo „da bi Moskva u ovoj i ovakovoj internacionalnoj situaciji bila reskirala ovakovu aferu, kada nebi bila sigurna svoje stvari“. Tito i partijski vrh „očajno dokazuju svoju lojalnost Moskvi i boljševizmu, a kao odgovor dobivaju sve stroži i nepomirljivije držanje Moskve, satelita i sveukupnoga svjetskoga boljševizma“" 89

Zaključno, „za našu je stvar pozitivno to, da dolje vlada nesigurnost, (...) da je u njihovim redovima nastala razklimavost, i da će i to doprinieti dizanju duha i budjenju nade, a to će stvarati i nove, sretnije mogućnosti za rad“. Pod uvjetom „da stvar prihvatimo za pravi kraj i ne počinimo kakovih krupnijih pogrješaka“. 90

Komunističke partije Jugoslavije održan od 21. do 28. srpnja 1948. u Beogradu, op. a.) spasiti glavu, nu tko zna, što će iza toga doći. Ovih je dana Ana Pauker (ministrica vanjskih poslova komunističke Rumunjske, op. a.) i otvoreno napisala, da se radi osobno o Titu, a čini se da su gospodarske sankcije svih satelita proti Jugoslaviji započele.“ (Pismo AS - Hansu, 4).

90 Pismo AS - Hansu, 4. „Sa domovinom je prekinuta svaka veza i to baš u času, kad su prilike tamo obzirom na lom u komunističkim redovima najpovoljnije za rad.“ Okružnica Lovre Sušića od 25. rujna 1948. godine u: N. Čolak, Akcija Deseti travnja, 356. 


\section{ZAKLJUČAK}

Kako se o ulozi Ante Pavelića u akciji „Deseti travnja“ nerijetko zaključuje na temelju memoarskog gradiva koje u pravilu nije osobito pouzdan izvor, istraživanju Pavelićeve uloge treba pristupiti koristeći dostupno arhivsko gradivo koje se odnosi na pripremu i tijek same akcije. Tu se u prvom redu misli na gradivo koje se nalazi u fondu SDS-a, a koje još uvijek nije dovoljno istraženo kad je riječ o ovom temi, ali od nezaobilazne važnosti je i Pavelićeva korespondencija. Raščlamba do sada nepoznatog Pavelićeva pisma najbližim suradnicima, u kojem se osvrće na posljedice akcije, pokazuje kako u njemu nema zapovjednog i autoritativnog tona. Iznose se savjeti, mišljenja i prijedlozi, ali ne zapovijedi. Ono što je također vidljivo raščlambom pisma je činjenica da u njemu nema nikakvog nagovještaja o boljoj upućenosti vezano za aktualne i buduće događaje. Također, ovaj prilog istraživanju akcije „Deseti travnja“ ukazuje i na potrebu daljnjih istraživanja u cilju rasvjetljavanja planiranja, provedbe i propasti same akcije, kao i posljedica koje je prouzrokovao njezin tragični završetak. Na koncu, još uvijek ne postoji monografija o akciji pa je potrebno popuniti i tu prazninu. 
Prilog 1. Pismo AS (pseudonim Ante (Antonio) Serdar za Ante Pavelić) Hansu (Ivan (Ivica) Krilić)

Izvor: Pismo se nalazi u autorovu posjedu

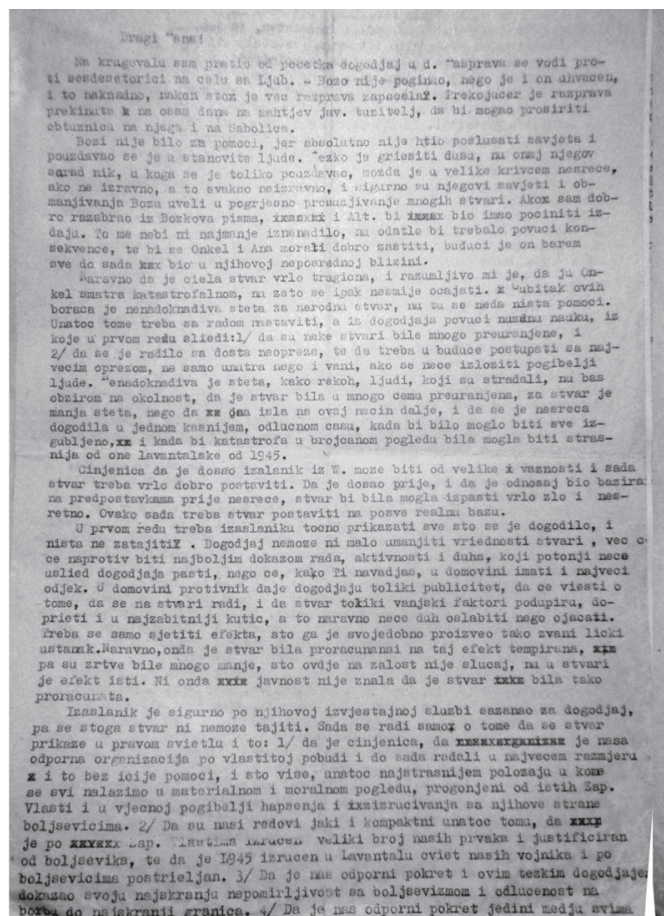

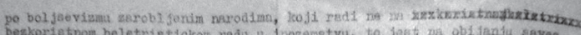

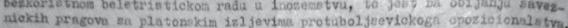

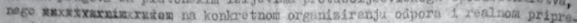

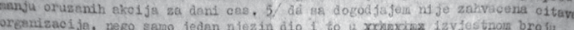

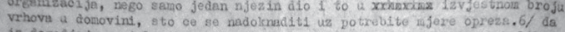

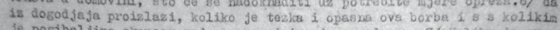

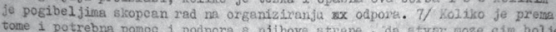

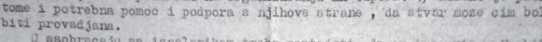

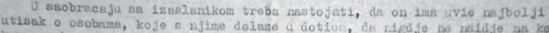

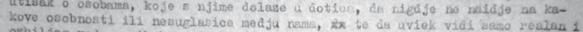

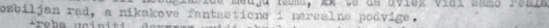

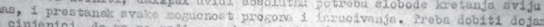
o cinjonto1, da

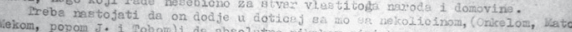

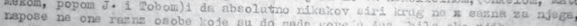

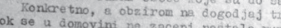

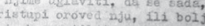

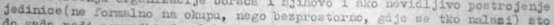

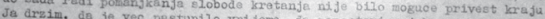

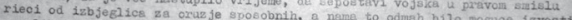

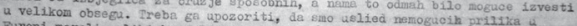

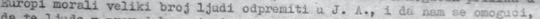

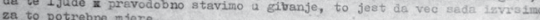

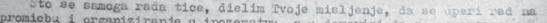

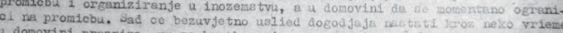

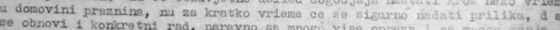

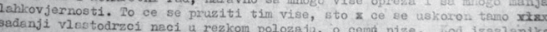
bi trebalo izhoúiti bezuvjetno tretunx

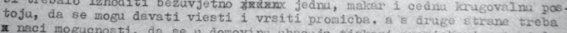

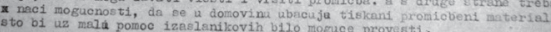

J buâuce nil fe nikakco aputno atvarati us domovini fodon olels forum

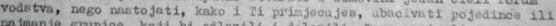
najmanje grupioe, koji bi odlasill 1 dolaz1lix, zamo os nivali soto teko ra

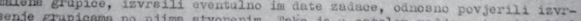

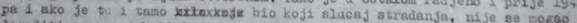

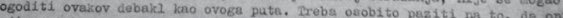

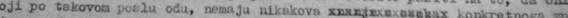
ja o osobars u Inozenetvu, ounoa no o $x$ njlhovom kretanju, o njihovom mjest

Konac no razumije se suano po eobi, de izaslanika treba upozoriti odmak

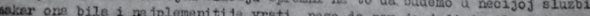
wavar on bile i ma fplemend tifo vreti, nego da nam je fedini cilj ontero 


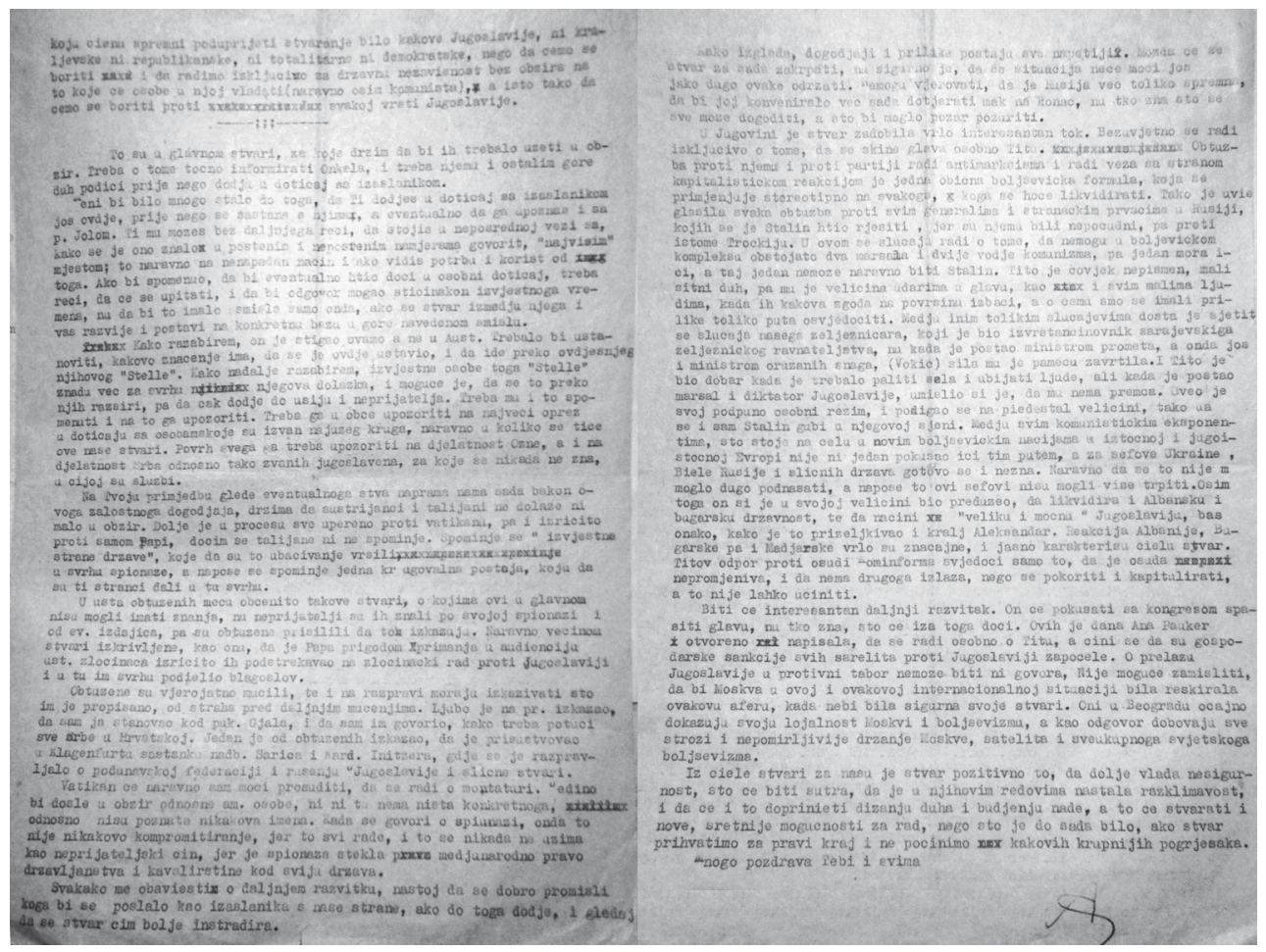


Ante DELIĆ

NEW TRIBUTES TO THE STUDY OF THE TENTH OF APRIL ACTION: THE UNKNOWN LETTER WRITTEN BY ANTE PAVELIĆ IN JULY 1948

\section{SUMMARY}

Conclusions related to the role of Ante Pavelić in the Tenth of April action have often been reached on the basis of memoir material, i.e. published testimonies of survivors, whose interpretations are full of inconsistencies. Therefore, research of Pavelićs role should be primarily based on available archive material on the preparation and the course of the action itself. The material that ought be studied is the one belonging to the holdings of the Secretariat of Internal Affairs of the Socialist Republic of Croatia - the State Security Service; this material has still not been sufficiently researched as concerns this topic. Pavelić's correspondence is in this context of major importance as well.

Concerning Pavelić's role in this action, two phases should be differentiated. The first phase included collecting reliable information on the state in the country. The objective was establishing a stable and secure link with the country. The second phase was operative, i.e. it included operating in the homeland, however only after the first phase had been brought to a successful ending. According to the knowledge gained from the research conducted so far, Pavelić insisted on the realization of the first phase as an imperative precondition for continuing operation in the homeland. However, Pavelićs role in the second phase of the action is much more complex.

The analysis of the so far unknown Pavelić's letter to his closest associates, where he tackles the consequences of the action, demonstrates no commanding or authoritative tone. He offers advice, opinions and suggestions, but issues no orders. The analysis of the text further reveals the fact that in the letter itself, there is no indication as to Pavelić having had any knowledge regarding present and future events. This tribute to the study of the Tenth of April action indicates furthermore to the need for follow-up research aiming at unveiling the planning process, the conducting and debacle of the action itself, as well as the consequences caused by its tragic ending. Up to the present, no monograph on this action has been written; this ought to be changed.

Keywords: Ante Pavelić; Božidar Kavran; Lovro Sušić; Ivica Krilić; Mate Frković; the Tenth of April action; Western intelligence agencies. 
